\title{
PLACE | DRESSING
}

\section{Peta Carlin}

\begin{abstract}
Philosopher Jeff Malpas once observed that '[p]art of the secret of a place lies in the other places with which it communicates'; suggesting that places are necessarily interconnected and cannot be experienced in isolation. PLACE DRESSING explores connections between Melbourne and the Outer Hebrides, and focuses on the relationship between the handcrafted, geographically specific and culturally grounded fabric of Harris Tweed, handwoven by islanders in their homes in the Hebridean islands, and the phenomenon of the mass-mediaised surface of the curtain glass wall (Figure 1) that patterns our cities across the world. Conceiving of place as a garment, this scholarly and poetic essay discusses the traditional practices involved in the production of Harris Tweed (Figure 2), and juxtaposes this fabric with the disconnected and globalised surface of the curtain glass wall. The vestiary metaphor is extended to encompass Gottfried Semper's concept of Bekleidung, and the concept of inhabitation is further explored. Departing from the reading of photographs juxtaposed, an image of a curtain wall façade and a swatch of Harris Tweed, this essay calls into question how we clothe the body and dress the building, in a weave that enables us to rethink the complex relationships between landscape, identity and place, and their investment in craft and design practices, with particular emphasis on textile design and architecture.
\end{abstract}

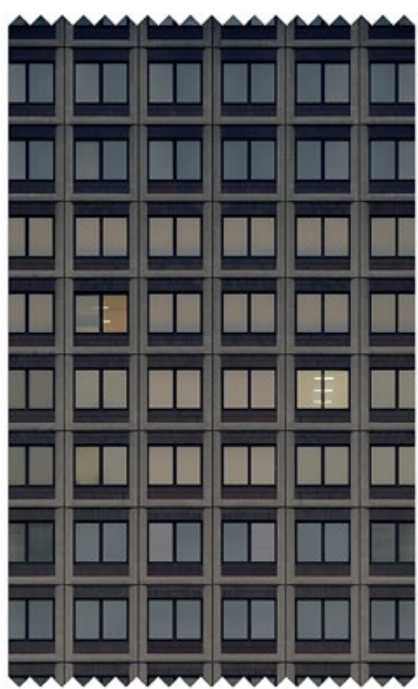

Figure 1. Peta Carlin, Cowen House from the Urban Fabric: Greige Series, 2007, photograph printed on Belgian linen, 1520 x $960 \mathrm{~mm}$

Copyright: Peta Carlin

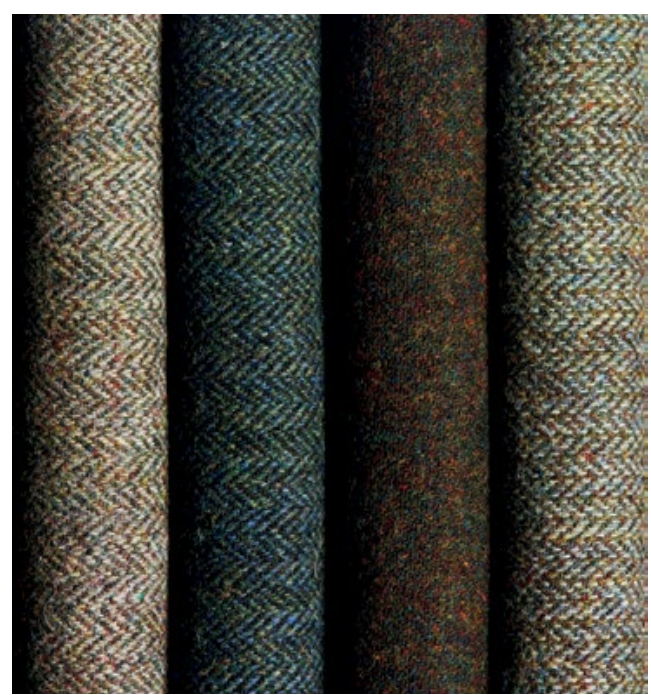

Figure 2. Harris Tweed herringbone weaves, c. 2002

Copyright: The Harris Tweed Authority 
Beings surround themselves with the places where they find themselves, the way one wraps oneself up in a garment.

-Georges Poulet

Everything that 'adorns' man can be ordered along a scale in terms of its closeness to the physical body. The 'closest' adornment is typical of nature peoples: tattooing. The opposite extreme is represented by metal and stone adornments, which are entirely unindividual and can be put on everybody.

-Georg Simmel

\section{Place as a garment}

An ancient scribe tells us that the Attic chiton ( $\chi \imath \tau \omega \dot{v} v)$ was originally designed by Aeschylus ${ }^{1}$ as a linen or woollen costume to be worn on the stage. This swathe of cloth elegantly draped, was later to be adopted by priests and torch-bearers, finding itself as an ornament to festivities, thereafter being worn by the populace at large (Mallgrave 1996: 296). Its prefacing figure, $X$ (chi), is reminiscent of a rudimentary signature as well as a mark of a destination, an address inscribed on a map. Such drapery also formed the mainstay of Highland wear, the feilidh mhor or large wrap (forerunner of the kilt) was similarly arranged, hitched higher however, and belted to the body. The tweed's malleable form shrouded the body, providing protection from the elements, and also operated as a minimal shelter, a makeshift domicile in the midst of the landscape. The big cloth, or clo mhor as Harris Tweed is known in Gaelic, and the large wrap are conceivably one and the same cloth and familiarly interchangeable.

In the waulking ${ }^{2}$ song 'This morning I have risen early', there is a line, '[a]nd in my tartan plaid I fold her' (Campbell 1969: 134-35) that speaks not only of the tender intimacies of courtship but, perhaps even more profoundly, of Harris Tweed's authenticity and its inextricable connectedness to place. The fabric's very situatedness is constitutive of its unique existence, and is further embodied in its rich history and its customs, which are held fast in oral form, the tradition continuing to this day and very much lived.

Fleeces continue to be sourced from the Blackface and the Cheviot sheep that wander the Hebridean islands' machair and mountainsides and, prior to the introduction of commercial dyes, the fibres were further coloured by that land: the tweed's variegated web infused plants indigenous to it. The mixture of specimens and mordents were closely guarded recipes that passed from one generation to the next, from mother to daughter (Thompson 1969: 31-34).

1 Aeschylus (c. 525/524 BC - c. 456/455 BC) was an ancient Greek tragedian.

2 Waulking is the fulling and finishing of the cloth, rendering it appropriate for wear. It was performed by women, 10 or so, and was accompanied by singing. The vast majority of the songs are of unknown origin and form part of a great oral tradition. 
In the Hebrides, the ling heather, or fraoch, bequeathed a deep green; stone parmelia or crotal lending red; cudbear (corcar) bestowing purple; woad (glas-lus or guirmean) instilling blue; with an intense yellow received from dyer's rocket or lus-bhuidhemor-these plants were only a handful that stained the wool, the dying undertaken in a large cast-iron vat prepared over a fire set in the open (Thompson 1969: 32-39). The different coloured wools were carded together and spun, with additional combinations in hue and tone ensured in the weaving of warp and weft. The fabric was further imbued by the scent of the weaver's peat fire, the web itself an iridescent and shifting landscape, sensorial and concinnous, incanted over during the waulking, its surface redolent with histories and local lore.

Enfolded in the feilidh mhor, the lovers were indistinguishable from the land; camouflaged and flattened, they were at one with it as they were with each other. While visibility was manifest in the craftsmanship of the cloth, re-immersed in the land it was drawn from it became indistinguishable-unified.

In ancient Greece, the visible surface, epiphaneia, was understood as a 'comingto-light', the bearer of 'prominence and impressiveness', qualities conferred upon it by the skilfulness of its weave, its association with conspicuousness said to be of lesser consequence (McEwen 1993: 87-88).

\section{Kosmos and adornment}

For the Greeks, kosmos, in its Homeric form, was generally understood as a 'rhythm or an order ... rediscovered with each new tracing of the figure' (McEwen 1993: 42), as is the case with Harris Tweed, with its endless permutations of patternation and colouration. The term kosmēse, however, also signifies arranging, ordering and adorning. Manifest in the acts of building and making, the crafted surface, its very appearing, was an acknowledgement of existence. So, when a woman adorned herself, kosmēse, wrapping her skin, chrōs (skin or colour), in yet another skin, she lent body, 'bring[ing] living surface-body so clothed to light; ... mak[ing] it appear' (McEwen 1993: 4344). The word 'cosmetics' takes its leave from such enhancement and recalls Baudelaire's advocating, '[m]aquillage has no need to hide itself or to shrink from being suspected; on the contrary, let it display itself, at least if it does so with frankness and honesty' (1993 (1863): 34). ${ }^{3}$ As 'a continuous coloured surface, a fabric' (Wigley 2001: 250), adornment was not simply understood as mere appliqué, a piecemeal embellishment, but rather as an enveloping, a swathing or draping, a dressing binding, yet abounding in its entirety: the adorned memorialising adornment. 
For Gottfried Semper, ${ }^{4}$ Greek architecture was conceived as 'the art form and decoration ... profoundly and intimately bound and influenced by [the] principle of surface dressing, [so much so] that it [was] impossible to consider them separately' (2004: 246). This understanding was to conceivably inform both architecture and vestiary arts from that time onward. Indeed, for Vitruvius, ${ }^{5}$ woven cloth facilitated not only the covering and protecting of the body, but also enabled adornment so that the fabric might enhance the body's honour (McEwen 1994: 134). It ensured visibility and allowed the wearer to assume one's place in the world. The Latin term honestas not only conferred honour, but was also a bestowal of reputation, character, respectability, virtue, integrity and dignity; esteemed Roman qualities and, hence, necessarily public (McEwen 1994: 138). For John Ruskin, ${ }^{6}$ adornment was conceived of as a form of ornament attendant to an existing structure, with architecture being proposed as 'an art that "adorns the edifice raised by man for whatsoever use", such embellishment understood as separate and lying in contradistinction to the surface to which it was applied (Benjamin 2006: 16). Semper conceived of adornment similarly, but understood it as a cosmic imperative, experienced as 'a manifestation of the universal world order within the phenomenal world' (Semper 2000 (1856): 91). Premised upon his theory of formal beauty, and its principle axes of symmetry and proportionality, coupled with directionality, such embellishment was co-extensive with his concept of dressing, conceivable as an all-encompassing ensemble-a Gesamtkunstwerk: a 'synthesis of the arts'. In adornment, as in dressing, '[c]entripetal and centrifugal tendencies [were understood as] fused', individual elements orchestrated through their very participation (Simmel 1950b: 343).

\section{Colour and dressing}

A legacy of his long-held interest in textiles, Semper's preoccupation with the woven cloth, it has been suggested, marks the culmination of his interests in polychromy (Mallgrave 1996: 290), 'light and colour ... treated as one ... heightened by the juxtaposition of fragments of pure hues' (van Zanten 1977: 63), recalling the Luminists' portrayal of the landscape and their concern with atmospherics. For Semper, such chromo-luminarism conceivably registered as a vestige of the ancient technique of toreutics, the weaving together of a diversity of stuffs, manifest now as colour, 'the subtlest and most incorporeal dressing' (Semper 2004: 379), a symbolic, indexical homage to the crafted, iridescent surface. For Semper and Benjamin, painted and applied, colour was

Gottfried Semper (1803-79), German architect and scholar.

Marcus Vitruvius Pollio (c. 80-70 BC - c. 15 BC), Roman architect and author.

John Ruskin (1819-1900), English art and social critic. 
understood as 'fluid, the medium of all changes' (Benjamin 1996 (1914-15): 50), binding disparate elements of a building together and further to their environment and surrounds, the play of light on these surfaces epitomising divinity.

For Semper, 'delight in colour' 'is fundamental to our being, residing in our instinct for play and adornment' (Semper 1989: 14). The interplay between the liminal materiality of colour with the varying intensity of light was to find its apotheosis in his theory of dressing, or Bekleidung as he was to term it, a principle that enabled him to 'posit a unitary origin for all the arts' (Rykwert 1976: 78). Its 'motives [while] borrowed from the realm of costume and finery' (Mallgrave 1996: 293) were evident earlier in his conception of the architectural enclosure (Semper 1989: 24).

Bekleidung is derived from the German kleiden, and is generally understood as 'to clothe' or 'to dress', finding its origins in kleit or cloth, which, upon further derivation, is revealed in the mixture applied to the cloth, klei, a clay or loam (Spelman 1997: 48), in order that it be fulled and waulked. The preparation and finishing of the cloth undertaken between loom and body, and by extension, the workmanship enacted upon stone between quarry and wall, enabled both cloth and stone to become wearable and, hence, inhabitable.

For Semper, speech, the spoken word, further supported his concept of dressing. Words were not simply 'linguistic symbols applied to building at a later stage but clear indications of the textile origin[s]' of architecture. Homonymous wordplays in German, his native tongue, revealed associations; analogies that informed the symbolic and unitary origins of the formal language of the arts as a whole. Correspondences between wand and gewand, wall and garment, associations between zaun, a hedge or fence, and saum, hem or fillet, further exemplified in the double meaning of decke as both ceiling and cover, manifested as the 'prearchitectural conditions' of 'dwelling [which were to] assume monumental form' (Semper 2004: 248).

Semper's founding of structural-symbolic ornamental motifs on the technical arts sought to expose 'universal principles that always retained a certain stylistic necessity', revealed, for example, in the correspondence between the triglyphs of the Doric temple and the fringed and decorative borders of fabrics, both the result of the need to terminate and resolve edge conditions (Semper 2004: 32). In these shifts between media and modes, a transfiguration occurs, movements reverberating between body and building, between the intimate and the architectural, regardless of scale, dressing. For:

In principle what the human body is to its coverings (cloth, cosmetic paint, or jewellery), load-bearing materials are to finishing materials. The analogy rests on equivalent 'experiences' of sheltering, modesty and decoration. In neither case was nakedness evident, not for stone nor flesh; in both cases there was something unseen and supporting, and something visible and supported. (Leatherbarrow 1993: 202-03) 
Semper's concept of dressing draws from an understanding of the festive nature of the theatre, 'the haze of carnival candles [being] the true atmosphere of art', replete with its religious nuances, which were given form, not only in the 'stone dramas by Phidias' (Semper 2004: 439, n. 85), ${ }^{7}$ but also on the festival stage, its bedecking informing his conception of monumental architecture, the anchoring of ritual in place and its rendering as tangible (Hvattum 2004: 67).

The festival apparatus-the improvised scaffold with all its splendour and frills that specifically marks the occasion for celebrating, enhances, decorates, and adorns the glorification of the feast, and is hung with tapestries, dressed with festoons and garlands, and decorated with fluttering bands and trophies - is the motive for the permanent monument, which is intended to proclaim to future generations the solemn act or event celebrated. (Semper 2004: 249).

For Semper, 'dressing and the mask [were] as old as human civilisation' (2004: 438-39, n. 85); the 'masking of reality' recalling the role of the mask in ancient Greece, those worn by the gods, in particular, which served 'to express tensions between contrary terms' (Vernant and Frontisi-Ducroux 1990: 206), manifest in the contest between that which is supported and that which is covered, a veiling, a veritable 'dissimulating fabric' inextricably woven into the 'fabrication of architecture' (Mallgrave 1996: 300). For the structure beneath the textile surface or mask operates as nothing more than a prop. It is 'merely a supporting player, playing the role of support, supporting precisely because it does not play' (Wigley 2001: 12). The outer surface is necessarily performative and is rendered so only in and through its dressing, differentiating itself from its fixed and voiceless scaffold, in an interplay between concealment and revelation.

\section{Enclosing and enclothing}

Semper's interest in the performing arts, however, was not limited to drama, but was also informed by dance and music; those 'cosmic arts' inspired by Mnemosyne and her sorory; mimesis, the forming of images as opposed to mere copies 'deriv[ing] from the star-dance of the heavens' (Gadamer 1986: 36). In ancient Greece, choros, earthbound, was understood not only as the dance floor or the dance place, but the very dance itself (McEwen 1993: 58). Place appeared with the dance, those sets of steps and turns figured and repeated, and dissolved when the dance was completed (McEwen, 1993: 63), place tethered in memory and lived, nonetheless.

7 Phidias (c. 480-430 BC), Greek sculptor and superintendent of the works undertaken on the Acropolis. 


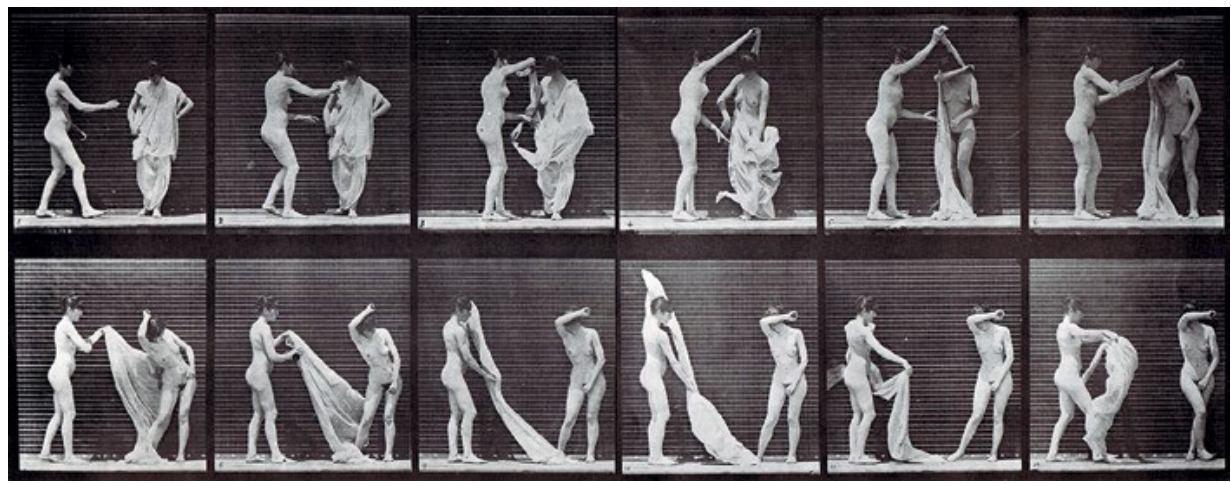

Figure 3. Eadweard Muybridge, 'Woman disrobing another', from Animal locomotion, 1887, plate 427

Source: Boston Public Library, www.digitalcommonwealth.org/search/commonealth:70796120x

The German words for wall and for garment, wand and gewand respectively, find their origins in wenden, 'to turn', as well as winden, 'to wind' or 'to twist' (Spelman 1997: 51), a surface enclosing, well-crafted, appearing. In the Hebrides, the cloth was waulked in a sunrise direction, turning round the table, as the cloth had previously been wound around its beam in the weaving, the cloth then tailored to encircle the body, as the walls enclosed the room in which the dressing took place. The wearer's journeying through the city, conceivably mirrored, more or less, the ancients' cycling movements about the polis and the very appearance of place (Malpas 2007: 494).

The word itself, polis (the ancient Greek city-state), is suggestive of a ring-wall, its Latin derivation, urbs, containing within it the figure of a circle, derived, as it is from the same root as orbis, from which we get orbit. The word 'town' comes to us through German and originated in the word zaun, a surrounding hedge or fence (Arendt 1958: 64, n. 64), which also bares comparison to saum, or hem (Semper 2004: 248). Semper posited 'the surrounding wall' (Einfassungsmauer) as the 'first element of antique architecture' as well as the 'primordial seed' (Urkeim); the wall germane to the dwelling, unfurling further to encompass both temple and city (1989: 23), drawing closer, conceivably clothing the body.

The curtain wall takes its name from the area between the bastions, its stretch enclosing and fortifying ancient citadels. Office towers, now thus attired form a sentinel and silent chorus, lining the streets, the city operating as a backdrop. Through the dilation of the camera's lens, a landscape is further revealed, at another focus, it discloses a room, stopping down again, architecture's textile foundations are brought to light. 


\section{Habit and inhabitation}

The city's architecture can be 'appropriated in a twofold manner: by use and by perception-or rather, by touch and sight' (Benjamin 1969 (1936): 240), though the other senses cannot be excluded and necessarily come into play. Engagement with built form cannot simply be grasped in its entirety through studied contemplation alone. Habitual use, too, informs our understanding of it and, to a large extent, even how we view it, its familiarity rendering it both preponderant and peripheral, its features registering only intermittently, in a distracted, non-concerted manner. For:

Lasting impressions, impressions which differ only slightly from one another, impressions which take a regular and habitual course and show regular and habitual contrasts all these use up, so to speak, less consciousness than does the rapid crowding of changing images, the sharp discontinuity in the grasp of a single glance. (Simmel 1950b: 410)

The mind, it has been suggested, is composed of two layers (Freud 2006 (1925): 22)-like the double-face of a wall, or a costume well-lined-with an inner receptive surface, and an outer protective shield. The concept of habit can be likewise conceived as a surface, separating the inner life from that which lies beyond. Habit springs from the Latin habitus, a noun conveying activity, which is derived from habere, to have or to hold, and is understood as the possession of interior qualities, a mode of being, and the cultivation of mental and moral traits, which result in a constitution that confers a 'power of use and enjoyment' (Bruno 2002: 322). But habit, similarly derived, also extends to exterior features and outward appearance; to modes of apparel, to fashion and dressing, but also through in-habitation to the place of abode, an ad-dress. For 'to dwell' is:

a transitive verb - as in the notion of 'indwelt space': herewith an indication of the frenetic topicality concealed in habitual behaviour. It has to do with fashioning a shell for ourselves. (Benjamin 2004: [14, 5])

Habit, too, takes on a performative role, through use and usage, customarily repeated, to the point where such action is performed unconsciously, eliciting a 'mechanical' reaction, an automatic response, the result of repetition. In our coursing through the city, on our daily journeys, liminal layers are acquired through our re-experiencing of the streets and the architecture that defines them. Threads are slowly woven through quotidian re-enactment, until a garment is gradually borne, lined with memories of other places, impressed upon us by the flurry of images, unconsciously clothing our existence. Inhabiting the city, we become increasingly attired in place, already enclothed ourselves. For:

[w] hen the scope of surface tactilism is extended, clothes, architecture, interior design, cosmetics, and the moving image appear as conterminous spaces of inhabitation. As the mutable skin of a social body, they are all part of a shared interactive experience. In defining our way of living space, 
they tailor our own contours. They shape our passage as moving surfaces in space and mark the traces we make along the way, for 'to live is to leave traces'. (Bruno 2002: 322)

'Erase the traces!' however, was an insistent refrain that echoed throughout the first decades of the twentieth century, a period heady with modernist zeal, which sought to dissociate itself from precedence, to disencumber itself of the weight of history (Benjamin 1999 (1933): 734). Progress was to seemingly take one form in the office building, which emerged as a new type, a 'house of work, of organisation, of clarity, of economy', a reductive construction unadorned and ossified, largely colourless and indifferent, 'by nature, skeletal' (Mies van der Rohe 1971: 74). New materials-concrete, iron and glass-were lauded: 'Scheerbart with his glass and the Bauhaus with its steel ... opened up the way: ... creat[ing] spaces in which it [was] difficult to leave traces' (Benjamin 1999 (1933): 734). ${ }^{8}$ Resistance was thus internalised, with concessions made by the plush nap of upholstery and its textiles (Benjamin 2004: [I3,1], [15,2]). A furtive and fugitive existence was proposed, life, its vitality diminished and depreciated, devoid of existential vestiges. Uncovered and exposed, '[r]educed to skin and bones', the office building was inexorably rendered as 'a jejune thing' divested and revealed as inconspicuous, lacklustre, another one among the many (Rykwert 1996: 382). Categorised according to its surface condition, while the comportment of the curtain wall was acknowledged, the metaphoric potential of the weave was ignored, and if it was read at all, was understood as 'speculative cubage wrapped in exterior wallpaper' (Martin 2001: 67-68). The grid in its repetition, repeated ad infinitum, resulting in a self-reflexive mise en abyme, a 'naked and determined materialism' (Krauss 1979: 52). The curtain wall's formalist drive in eschewing its textile origins, thus revealed a massreproduced surface, 'detache[d] from the domain of tradition' (Benjamin 1999 (1936): 221).

\section{Place and colour}

It is said that "[i]f the place enriches the being who is found there, the being confers on the place where it is found something of its own individuality' (Poulet 1977: 28). Or, perhaps to put it another way, we are coloured by placedyed in the wool, so to speak-but so too do we cast upon it our own hues and enliven it, as we (the very threads of our being) interweave between here and there enclosed in place, moving in between, and in certain lights, igniting. For colour that imbues the woven cloth, like place, is by nature reflexive, 'encompass[ing] that on which it reflects - ... but never fully illuminat[ing] that which it encompasses' (Malpas 2008: 10). Place and colour are both inextricably linked and revealed in the shifting, animate and dynamic nature of the surface,

8 Paul Scheerbart (1863-1915), German author, closely associated with German expressionist architecture, and in particular, with the work of the architect Bruno Taut (1880-1938). 
whether woven, painted, knitted or built. Chiasmatic in their tidal unfurlings and enfoldings, from the intimate to the architectural, place and cloth dress, binding the body to its environment, to the landscapes and its surrounds, to the city and the buildings which compose it. Contexts immediately apparent are thus established, and span across divides, with latent memories concealed within the folds and revealed and complemented in their afterimages.

Peta Carlin is a Melbourne-based artist and essayist. She graduated from architecture, prior to undertaking degrees in fine art, and her $\mathrm{PhD}$ was awarded in 2013. Peta has a particular interest in the nature of the surface and its significance in our understanding and experience of place. Her work explores relationships between architecture and textiles through the practices of image-making with a view to collaborative exchange. Her forthcoming book On Surface and Place: Between Architecture and Textiles will be published by Ashgate.

\section{References}

Arendt, H., 1958, The Human Condition, 2nd edn, University of Chicago Press.

Baudelaire, C., 1993 (1863), 'The painter of modern life', in J. Mayne (ed. and trans.), The Painter of Modern Life and Other Essays, London: Phaidon Press, pp. 1-41.

Benjamin, A., 2006, 'Surface effects: Borromini, Semper, Loos', Journal of Architecture, vol. 11, no. 1, pp. 1-36.

Benjamin, W., 2004, The Arcades Project, H. Eiland and K. McLaughlin (trans.), Cambridge, MA: Belknap Press of Harvard University Press.

—, 1999 (1933), 'Experience and poverty', R. Livingstone (trans.), in M.W. Jennings, H. Eiland and G. Smith (eds), Selected Writings: Volume 2, 19271934, Cambridge, MA: Belknap Press of Harvard University Press, pp. 731-36.

--, 1996 (1914-15), 'A child's view of colour', R. Livingston (trans.), in M. Bullock and M.W. Jennings (eds), Selected Writings: Volume 1, 19131926, Cambridge, MA: Belknap Press of Harvard University Press, pp. 50-51.

- 1969 (1936), 'The work of art in the age of mechanical reproduction', in $\mathrm{H}$. Arendt (ed.), Illuminations: Essays and Reflections (H. Zohn, trans.), New York: Schocken Books, pp. 217-52.

Bruno, G., 2002, Atlas of Emotion: Journeys into Art, Architecture, and Film, New York: Verso. 
Campbell, J.L. (ed.), 1969, Hebridean Folksongs: A Collection of Waulking Songs by Donald MacCormick in Kilphedir in South Uist in the Year 1863, London: Oxford University Press.

Freud, S., 2006 (1925), 'A note on the mystic writing-pad', in C. Merewether (ed.), The Archive: Documents of Contemporary Art, London: Whitechapel and Cambridge, MA: MIT Press, pp. 20-24.

Gadamer, H.-G., 1986, 'The relevance of the beautiful', in R. Bernasconi (ed.), The Relevance of the Beautiful and Other Essays (N. Walker, trans.), Cambridge University Press, pp. 1-53.

Hvattum, M., 2004, Gottfried Semper and the Problem of Historicism, Cambridge University Press.

Krauss, R., 1979, ‘Grids', October, vol. 9, pp. 50-64.

Leatherbarrow, D., 1993, The Roots of Architectural Invention: Site, Enclosure, Materials, New York: Cambridge University Press.

McEwen, I.K., 1994, 'Instrumentality and the organic assistance of looms', in A. Pérez-Gómez and S. Parcell (eds), Chora 1: Intervals in the Philosophy of Architecture, Montreal: McGill University Press, pp. 123-42.

—, 1993, Socrates' Ancestor: An Essay in Architectural Beginnings, Cambridge, MA: MIT Press.

Mallgrave, H.F., 1996, Gottfried Semper: Architect of the Nineteenth Century, New Haven, CT: Yale University Press.

Malpas, J., 2008, 'Repetitions', in Repetitions, Hobart: Plimsoll Gallery, pp. 6-20.

— 2007 , 'Heidegger in Benjamin's city', Journal of Architecture, vol. 12, no.5, pp. 489-97.

Martin, R., 2001, 'Atrocities. Or, curtain wall as mass medium', Perspecta, 32, pp. 67-75.

Mies van der Rohe, L., 1971 (1923) 'Working theses', in U. Conrads (ed.), Programs and Manifestos on 20th-Century Architecture, Cambridge, MA: MIT Press, p. 74.

Poulet, G., 1977, Proustian Space, E. Coleman (trans.), Baltimore, MD: John Hopkins University Press.

Rykwert, J., 1996, The Dancing Column: On Order in Architecture, Cambridge, MA: MIT Press.

--, 1976, 'Gottfried Semper and the conception of style', in Gottfried Semper und die Mitte des 19.Jahrhunderts, Basel: Birkhäuser, pp. 67-83. 
Semper, G., 2004, Style in the Technical and Tectonic Arts; or, Practical Aesthetics, H.F. Mallgrave and M. Robinson (trans.), Los Angeles: Getty Research Institute.

—-, 2000 (1856), 'From 'Concerning the formal principles of ornament and its significance as artistic symbol', D. Britt (trans.), in I. Frank (ed.), The Theory of Decorative Art: An Anthology of European and American Writings, 17401940, Connecticut: Yale University Press, pp. 91-115.

- 1989, The Four Elements of Architecture and Other Writings, H.F. Mallgrave and W. Herrmann (trans.), Cambridge University Press.

Simmel, G., 1950a, 'Adornment', in K.H. Wolff (ed. and trans.), The Sociology of Georg Simmel, Glencoe, IL: Free Press, pp. 338-44.

- , 1950b, 'The metropolis and mental life', in K.H. Wolff (ed. and trans.), The Sociology of Georg Simmel, Glencoe, IL: Free Press, pp. 409-24.

Spelman, E.R., 1997, Gottfried Semper and the Profound Surface of Architecture, Master of architecture thesis, Rice University.

Thompson, F., 1969, Harris Tweed: The Story of a Hebridean Industry, Newton Abbot: David and Charles.

van Zanten, D., 1977, The Architectural Polychromy of the 1830's, New York: Garland Publishing.

Vernant, J.-P. and Frontisi-Ducroux, F., 1990, 'Features of the mask in Ancient Greece', in J.-P.Vernant and P. Vidal-Naquet (eds), Myth and Tragedy in Ancient Greece (J. Lloyd, trans.), New York: Zone Books, pp. 189-206.

Wigley, M., 2001, White Walls, Designer Dresses: The Fashioning of Modern Architecture, Cambridge, MA: MIT Press. 
This text is taken from Craft + Design Enquiry, Issue 7, 2015, edited by Kay Lawrence, published 2015 by ANU Press, The Australian National University, Canberra, Australia. 